A N N A LES

UNIVERSITATIS MARIAE CURIE-SKŁODOWSKA

LUBLIN - POLONIA

VOL. LXIII, 2

SECTIO G

2016

Uniwersytet Marii Curie-Skłodowskiej w Lublinie

krzysztof.amielanczyk@poczta.umcs.lublin.pl

KRZYSZTOF AMIELAŃCZYK

\title{
W poszukiwaniu antycznej genezy klauzul generalnych, czyli o wartościach i wartościowaniu w prawie rzymskim
}

In the Search of the Antic Origin of the General Clauses or on the Values and Valuations in the Roman Law

1.

Stawiając sprawę pryncypialnie, ktoś mógłby stwierdzić, że Rzymianie nie znali takiej kategorii pojęciowej, jak „klauzula generalna”, „klauzula odsyłająca” czy też „zwrot niedookreślony”. Byłaby to jednak mylna ocena, sformułowana z nieuprawnionym uproszczeniem, wywiedziona zapewne $\mathrm{z}$ faktu nieobecności odpowiednich, analogicznych zwrotów w języku łacińskim. Braki językowe nie powinny wszakże odwodzić od poszukiwania genezy współcześnie rozumianych klauzul w antycznym prawie rzymskim. Równie dobrze można wskazać, że Rzymianie nie nazywali wielu innych kategorii prawnych, którymi dzisiaj się posługujemy, takich jak choćby przykładowo: „,wada oświadczenia woli”, „prawo podmiotowe”, „nadużycie prawa” w obszarze prawa prywatnego czy też „kontratyp” przestępstwa, „formy stadialne i zjawiskowe” czynu zabronionego w obszarze prawa karnego - a przecież nawet one są bez większych zastrzeżeń odszukiwane przez romanistów w antycznych źródłach ${ }^{1}$. Brak wypracowania odpowiedniej na-

1 Poszukiwanie genezy współczesnych instytucji prawnych w prawie rzymskim jest zawsze zadaniem inspirującym, ale także często trudnym i ryzykownym. W. Dajczak (Błędy poznawcze a tęsknota za użytecznościa prawa rzymskiego, „Forum Prawnicze” 2013, z. 3, s. 11) przestrzega przed bezkrytycznym podchodzeniem do antycznego tekstu źródłowego w pogoni za dowodami użyteczności prawa rzymskiego dla współczesnego prawnika. Pamiętając o zwodniczości tzw. szybkiego myślenia, które dość często można spotkać w badaniach związków rzymskiego prawa 
zwy, zaniechanie kategoryzacji, a już na pewno unikanie definiowania i tworzenia teoretycznych, abstrakcyjnych konstrukcji przez jurystów rzymskich nie powinny nikogo dziwić, kto choćby w ramach studiów uniwersyteckich zetknął się ze specyfiką prawa rzymskiego ${ }^{2}$.

W niniejszym opracowaniu zostanie podjęta próba przeprowadzenia dowodu, że prawo rzymskie, choć nie zbudowało teoretycznej konstrukcji odpowiadającej współczesnej „klauzuli generalnej”, to korzystało jednak z niej niemal bezwiednie, jakże często wbudowując stosowny schemat myślowy w reguły prawniczego rozumowania. Dla pewnego uproszczenia, ale i uczynienia dalszego wywodu bardziej klarownym, należało przyjąć jakieś umowne ramy definicyjne rzeczonej (współczesnej) instytucji prawnej. Oczywiście z pełną świadomością prowadzonej, wciąż ożywionej i niezakończonej dyskusji w polskiej nauce prawa, czym jest „klauzula generalna”3. Przyjmijmy zatem, że klauzula generalna jest z założenia niedookreślonym zwrotem użytym $\mathrm{w}$ przepisie prawnym, wymagającym w procesie stosowania prawa wypełnienia go treścią przez niezbędne wartościowanie, ocenianie i szacowanie z zastosowaniem niewskazanych bliżej kryteriów. To wartościowanie towarzyszące argumentacji prawniczej nie podważa wszakże jej profesjonalizmu, chociaż odwołuje się często do ocen właściwych i zrozumiałych w środowiskach innych niż prawnicze. Obecność klauzul generalnych zwiększa w sposób oczywisty swobodę orzeczniczą, pozwalając na indywidualną ocenę każdego jednostkowego przypadku. Ponadto czyni z pewnością prawo bardziej elastycznym w stosowaniu, co pozwala na unikanie zbyt częstych zmian normatywnych. Klauzule sprzyjają tym samym stabilności prawa oraz bardziej ewolucyjnym niż rewolucyjnym zmianom. Romanistyka prawnicza nie zajmowała się, z tego, co mi jest wiadomo, teoretycznym problemem, jakim jest konstrukcja klauzuli generalnej w odniesieniu do prawa rzymskiego. Jednakże, z drugiej strony, wyjątkowo dużo miejsca, także w nauce polskiej, poświęcono jego ponadczasowym wartościom etycznym. Przy bliższym przyjrzeniu się rutynowo omawianym w ramach tego typu opracowań kwestiom okazuje się, że wspomniane wartości prawa rzymskiego są werbalizowane nie tylko przez naukowe oceny

prywatnego z prawem współczesnym, ograniczyć się raczej przyjdzie w niniejszym krótkim opracowaniu do wskazania zaskakujących podobieństw współczesnych klauzul do schematów rzymskiego rozumowania, bez aspiracji do wykazania pełnego ich historycznego rodowodu.

2 Zob. przykładowo na temat specyfiki pracy rzymskiej jurysprudencji: W. Litewski, Jurysprudencja rzymska, Kraków 2000, s. 49 i n., 119 i n.; M. Kuryłowicz, Prawo rzymskie. Historia - tradycja - współczesność, Lublin 2003, s. 65 i n.

3 Zob. tylko przykładowo: A. Wolter, J. Ignatowicz, K. Stefaniuk, Prawo cywilne. Zarys części ogólnej, Warszawa 2001, s. 76 i n.; L. Leszczyński, Pojęcie klauzuli generalnej, „Annales UMCS. Sectio G” 1991, nr 38, s. 158-163; idem, Tworzenie generalnych klauzul odsyłajacych, Lublin 2000, s. 25; Z. Radwański, M. Zieliński, Uwagi de lege ferenda o klauzulach generalnych w prawie prywatnym, „Przegląd Legislacyjny” 2001, nr 2, s. 11 i n.; J. Nowacki, O przepisach zawierajacych klauzule generalne, [w:] Studia z teorii prawa, Kraków 2003, s. 133 i n. 
piszących o wysokim poziomie rzymskiej kultury prawnej, ale przede wszystkim tkwią w samym języku normatywnym używanym przez jurystów rzymskich. Poddane analizie odpowiednie łacińskie zwroty, jeśli tylko zostaną zaprezentowane w odpowiednich polskich tłumaczeniach, wielokrotnie przywiodą na myśl współczesne, najbardziej znane i dyskutowane klauzule generalne.

Prawo rzymskie, choć miało swoje ustawy, konstytucje cesarskie i edykt pretorski, było jednak w swym najlepszym okresie rozwoju, tj. w okresie klasycznym, przede wszystkim jurysprudencyjne ${ }^{4}$. W konsekwencji trzeba zauważyć, że było tworzone i rozwijane przede wszystkim w oparciu o dyskurs tyleż naukowy, co praktyczny (kazuistyczny), prowadzony przez uczonych prawników - iuris prudentes. Wykładnia wartościująca, z której wręcz słynęło prawo rzymskie, pochodziła od jurystów i o niej wiemy najwięcej. Prowadzona była w oparciu o tzw. rationes decidendi, wypracowywane przez uczonych prawników na przestrzeni wieków ${ }^{5}$. Nie mówimy tu jednak o wykładni organu stosującego prawo we współczesnym tego słowa znaczeniu. Mówimy, jeśli w ogóle termin „wykładnia” jest tu odpowiedni, o poglądach na kształt obowiązującego prawa, prezentowanych publicznie przez uczonych jurystów ${ }^{6}$. Nie mówimy tu także o poglądach „doktryny" w takim sensie, jak mówimy o współczesnej nauce prawa, której ustalenia nie mają przecież jakiejkolwiek mocy wiążącej. Gdy definiujemy rzymskie responsa uczonych jurystów, mówimy o prawie rzymskim w ujęciu przedmiotowym w ścisłym tego słowa znaczeniu ${ }^{7}$. Jurysprudencja była podstawowym, najważniejszym źródłem rzymskiego prawa prywatnego ${ }^{8}$. Wypowiedzi jurystów wyposażonych $\mathrm{w}$ ius publice respondendi ex auctoritate principis (,,prawo do publicznego udzielania odpowiedzi pod autorytetem cesarza") nosiły bowiem charakter prawa obo-

4 Zob. T. Giaro, Interpretacja jako źródło prawa-dawniej i dziś, „Studia Prawnoustrojowe” 2007, nr 7, s. 243 i n.

5 Syntetycznie na temat rationes decidendi rzymskich jurystów zob. W. Litewski, Jurysprudencja rzymska, s. 127 i n.; szerzej: F. Horak, Rationes decidendi. Entscheidungsbegründungen bei den alteren römischen Juristen bis Labeo, Insbruck 1969, passim.

6 Na problem odróżnienia wykładni od interpretacji na gruncie badań nad prawem rzymskim zwrócił uwagę W. Rozwadowski, Etiam clarum iu exigit interpretationem, [w:] $W$ poszukiwaniu dobra wspólnego. Ksiega jubileuszowa Profesora Macieja Zielińskiego, red. A. Choduń, S. Czepita, Szczecin 2010, s. 39 i n.

7 Gajus (G. 1,2) wymieniał responsa wśród źródeł prawa: Responsa prudentium sunt sententiae et opiniones eorum, quibus permissum est iura condere. Quorum omnium si in unum sententiae concurrunt, id quod ita sentiunt, legis vicem optinet; si vero dissentiunt, iudici licet quam velit sententiam sequi („,Odpowiedziami znawców prawa były poglądy i opinie tych prawników, którym wolno było tworzyć prawa. W przypadku zgodności ich poglądów, taki zgodny pogląd miał moc ustawy. W przypadku braku zgodności, sędzia mógł pójść za poglądem jurysty przez siebie wybranym").

8 Responsa z czasem zostaną wyparte przez konstytucje cesarskie, głównie reskrypty, które miały zapewnić cesarzom dominujący wpływ na prawo i zlikwidować niepewność prawa z uwagi na różnice w poglądach jurystów. 
wiązującego i miały stanowić iuris auctoritas, czyli „wzmocnienie powagi prawa", jak twierdził w swym dziele o historii jurysprudencji rzymskiej Pomponiusz (D. 1, 2, 2, 49)9. Uzupełniająco można dodać, że opinie jurystów stanowiły swoiste ius controversum, tj. prawo rodzące się w wyniku ciągłego dyskursu prawniczego. Normatywny charakter opinie uzyskiwały więc stopniowo w oparciu o autorytet danego autora wypowiedzi, zwłaszcza wtedy, gdy został potwierdzony przez ius publice respondendi oraz gdy na dany temat wypracowano w dyskursie jurysprudencyjnym swoistą communis opinio ${ }^{10}$. W responsach jurystów można wskazywać liczne przykłady określeń wartościujących odnoszących się do kategorii prawnych rozważanych na gruncie konkretnych stanów faktycznych. Wzbogacały je one treściowo, jednocześnie pomagając we właściwej aplikacji prawa. Jeszcze lepiej widoczny był wkład jurystów w budowę ius civile, gdy interpretatio prudentium działała w swoistej ,próżni normatywnej”, wywodząc swe opinie z obowiązujących zwyczajów społecznych ${ }^{11}$. Jak twierdził Pomponiusz, stanowiła ona wręcz podstawę prawa cywilnego ${ }^{12}$.

Prawo rzymskie, jako „interpretacyjne” z założenia, nie było więc nastawione na mnożenie przepisów ${ }^{13} \mathrm{~W}$ celu objęcia ich dyspozycjami możliwie wielu napotykanych w praktyce prawa stanów faktycznych. Według zgodnej opinii Celsusa, Pomponiusza i Paulusa prawa powinno się bowiem stanowić jedynie dla przypadków najczęstszych (D. 1, 3, 3-6). W podobnym duchu, głosząc prymat interpretacji, wypowiadał się także Julian, twierdząc, że ustawa nie jest w stanie objąć wszystkiego (D. 1, 3, 10-12) ${ }^{14}$. Powyższa jurysprudencyjna interpretacja, przekazywana następnie zadającym pytania sędziom, odbywała się często przez odesłanie ich do własnych ocen, ale z zastosowaniem podpowiadanych kryteriów wartościujących. Tak tworzone przez jurystów klauzule nadawały prawu rzymskiemu elastyczność i ponadczasowość. Mogło ono - niepoddawane zbyt częstym zmianom swej normatywnej, stanowionej w ustawach, treści - ewoluować przez

9 Et, ut obiter sciamus, ante tempora Augusti publice respondendi ius non a principibus dabatur, sed qui fiduciam studiorum suorum habebant, consulentibus respondebant: neque responsa utique signata dabant, sed plerumque iudicibus ipsi scribebant, aut testabantur qui illos consulebant. Primus divus Augustus, ut maior iuris auctoritas haberetur, constituit, ut ex auctoritate eius responderent: et ex illo tempore peti hoc pro beneficio coepit.

10 T. Giaro, Interpretacja ..., s. 245.

11 W. Dajczak, T. Giaro, F. Longchamps de Bérier, Prawo rzymskie. U podstaw prawa prywatnego, wyd. 2, Warszawa 2014, s. 68.

12 D. 1, 2, 2, 12: Ita in civitate nostra aut iure, id est lege, constituitur, aut est proprium ius civile, quod sine scripto in sola prudentium interpretatione consistit.

13 Zob. W. Litewski, Jurysprudencja rzymska, s. 119 i n.

14 Szczególnie dobrze znana jest wypowiedź jurysty Juliana (D. 1, 3, 10), wedle której ustawy i uchwały senatu nie mogą przewidzieć wszystkich możliwych przypadków i dlatego uwzględniają najczęściej zdarzające się sytuacje: Neque leges neque senatus consulta ita scribi possunt, ut omnes casus qui quandoque inciderint comprehendantur, sed sufficit ea quae plerumque accidunt contineri. 
ciągłą prawotwórczą interpretację dokonywaną przede wszystkim w responsach jurystów, ale także - na co nie ma tu miejsca, by temat rozwijać - w edykcie pretorskim i reskryptach cesarskich.

Responsa jurystów rzymskich, oprócz opisanego wyżej normatywnego charakteru, który z formalnych względów pozwala zająć się nimi w poszukiwaniu korzeni instytucji klauzuli generalnej w prawie rzymskim, miały jeszcze jeden dodatkowy walor nasuwający nieodparcie myśl o antycznym prototypie tej instytucji. Responsa były udzielane w odpowiedzi na zapytania sędziów i urzędników jurysdykcyjnych. Ani rzymski pretor, ani sędzia nie byli prawnikami. Nie wystarczało im prawo w wersji oryginalnej, surowej, wywiedzione z ustaw i uchwał senatu, potrzebne im było prawo poddane uczonej prawniczej interpretacji, w takiej postaci, aby można je było zaprząc do działania w procesie orzeczniczym. Musiało to być prawo pozwalające na elastyczność, ale i podejmowanie roztropnych, słusznych rozstrzygnięć sądowych. Tu właśnie można dostrzec przestrzeń, w której mógł się pojawić zaczyn dla powstawania klauzul generalnych. Juryści odpowiadali wprawdzie w realiach przedstawionego im stanu faktycznego, lecz często kierowali się następnie ku uogólnieniom, tłumacząc zajęte stanowisko tak, aby sposób argumentacji przydał się również w innych, podobnych sprawach. Pomimo tego, że prawo rzymskie było „kazuistyczne", a juryści rozpoczynali swą pracę od analizy konkretnego stanu faktycznego, zaraz przechodzili jednak na poziom analizy napotkanego problemu prawnego z uwzględnieniem czy to jego szerszego kontekstu, czy to innych fikcyjnych wariantów stanów faktycznych, które ,przy okazji” warto było skomentować ${ }^{15}$. Juryści, uzasadniając swe responsa, sięgali po zwroty mające pokazać drogę, jaką powinna pójść argumentacja sędziego, a tę drogę wyznaczały zwroty wartościujące. Widoczne jest tu podobieństwo do współczesnego mechanizmu działania klauzuli generalnej, który ewidentnie łączy ze sobą celowo niedookreślony zwrot zawarty w przepisie prawa z luzem decyzyjnym sędziego, który to sędzia wzywany jest przez prawodawcę do podjęcia wysiłku wartościowania w ramach stosowania prawa.

Rzymscy pretorzy i sędziowie takich interpretacyjnych, wartościujących wskazówek potrzebowali jeszcze bardziej, i to nie tylko dlatego, że nie byli z wykształcenia prawnikami. Prawo rzymskie było słabo rozwinięte w swej warstwie ustawodawczej, tworzonej na zgromadzeniach ludowych czy plebiscytach. Niewiele było ustaw, brakowało kodeksów ${ }^{16}$. W sposób naturalny mogły się rodzić

15 Zob. T. Giaro, Interpretacja..., s. 247.

16 Niektórzy twierdzą, że stąd wzięła się wielkość prawa jurysprudencyjnego. Zob. W. Dajczak, T. Giaro, F. Longchamps de Bérier, op. cit., s. 72. Twórczy wkład w rozwój prawa rzymskiej jurysprudencji mógł się brać z niedostatków rzymskiej legislacji. Zob. więcej: T. Giaro, Interpretacja..., s. 244. 
w rzymskiej jurysprudencji pomysły na „doposażanie” w ramach interpretatio prudentium skąpego prawodawstwa w zwroty, które pozwalały na jego właściwe elastyczne stosowanie przez indywidualne wartościowanie w procesie dochodzenia do decyzji orzeczniczej.

Czas na wskazanie choćby niektórych, ale najbardziej istotnych przykładów zwrotów rzymskich przypominających współczesne klauzule generalne. Wielokrotnie mogą one uchodzić za pierwowzory klauzul obecnych albo proponowanych do wprowadzenia (przywrócenia) w naszym prawie. Jeśli chodzi o prawo prywatne, charakter zwrotów niedookreślonych, wymagających każdorazowo wypełniania ich treścią, miały przykładowo takie określenia, jak: bona fides (dobra wiara), bonos mores (dobre obyczaje) ${ }^{17}$, bonum et equum (dobre i słuszne), ratio aequitatis (słuszne powody), utilitas (użyteczność), natura rerum (natura rzeczy) itd. ${ }^{18} \mathrm{~W}$ rzymskim prawie karnym, podobnie jak w prawie współczesnym, rola klauzul generalnych była mniejsza, ale także można odnaleźć stosowne przykłady użycia takich zwrotów, jak np.: ratio aequitatis (racja słuszności), utillitas publica (korzyść, interes publiczny) czy dolus malus (zły zamiar) ${ }^{19}$.

Każdy z nich mógłby stanowić przedmiot osobnej dyskusji. Taka dyskusja trwa zresztą od dawna, nie brakuje polsko- i obcojęzycznej literatury traktującej o różnych aspektach argumentacji rzymskiej jurysprudencji, gdzie powyższe pojęcia stanowią punkt wyjścia, do której można by natychmiast odesłać. Jeśli chodzi o naukę polską, dość powiedzieć, że na naszym Wydziale odbyła się przed kilkoma laty konferencja dotycząca zasady słuszności, w jej rozmaitych wcieleniach, podczas której zostały wygłoszone dwa romanistyczne referaty, opublikowane następnie jako artykuły w „Studia Iuridica Lublinensia”: M. Kuryłowicza o pojęciu aequitatis $\mathrm{w}$ prawie prywatnym rzymskim ${ }^{20}$ oraz piszącego te słowa $-\mathrm{o}$ za-

17 W praktyce określenie adversus bonos mores. Zob. D. Nowicka, Zniesławienie w prawie rzymskim, Wrocław 2013, s. 105 i n. W szczególności na uwagę zasługują przekazy Ulpiana i Paulusa, zamieszczone w tytule X księgi XLVII Digestów - De iniuriis et famosis libellis (D. 47, 10).

18 W. Dajczak, The Nature of the Contract in Reasoning of Civilian Jurists, Poznań 2012, s. 128-130; idem, ,Natura umowy” w argumentacji prawników rzymskich, [w:] Consul est iuris et patriae defensor. Księga pamiatkowa dedykowana Andrzejowi Kremerowi, Warszawa 2012, s. 29 i n.

19 Wymieniono tutaj tylko te klauzule, które miały uniwersalny charakter. Klauzul bardzie szczegółowych było znacznie więcej, np. iniuria atrox - „ciężka zniewaga” (zob. K. Amielańczyk, Crimina legitima w rzymskim prawie publicznym, Lublin 2013, s. 211 i n.) czy „znaczny ciężar” przestępstwa popełnianego przez złodziei bydła - abigei (Ulp. Coll., 11, 7, 2).

${ }^{20}$ Co ciekawe, analizując różne znaczenia aequitas w prawie rzymskim, autor skojarzył klauzulę słuszności jako normę uzupełniającą prawo także ze współczesną klauzulą generalną. Por. M. Kuryłowicz, Wokół pojęcia aequitas w prawie rzymskim, „Studia Iuridica Lublinensia” 2011, t. 15 , s. 18 . 
sadzie słuszności w rzymskim prawie karnym ${ }^{21}$. Pojęciu bona fides monografię i kilka znaczących artykułów poświęcił przed kilkoma laty Wojciech Dajczak ${ }^{22}$. Klauzulą veritas (kryterium prawdy i fałszu), czyli prawdziwości (racjonalności) sądów głoszonych przez jurystów, zajmował się Tomasz Giaro $^{23}$, pojęciem sprawiedliwości iustitia - Bronisław Sitek $^{24}$. O różnych klauzulach, zazwyczaj akcentując $\mathrm{w}$ ten sposób ponadczasowe wartości prawa rzymskiego, pisali liczni polscy badacze: Borys Łapicki, Henryk Kupiszewski, Wiesław Litewski, Janusz Sondel, Marek Kuryłowicz, Witold Wołodkiewicz i wielu, wielu innych. Z powyższego względu, ale i z braku wystarczającego miejsca na poświęcenie stosownej uwagi choćby najważniejszym wymienionym wyżej zwrotom niedookreślonym, zdecydowałem się na poczynienie kilku uwag o zaledwie jednym z nich - klauzuli dolo malo, znanej z prawa karnego publicznego, terenu bliskiego moim własnym zainteresowaniom naukowym. Być może nie jest ona akurat reprezentatywna dla całego prawa rzymskiego, pozwoli jednak - jak sądzę - nieco przybliżyć mechanizm działania rzymskiej „klauzuli generalnej”.

Rzymskie prawo karne publiczne nie było tak dobrze rozwinięte, jak prawo prywatne i nie zostało nawet wyodrębnione w osobny system. Mniejszy zasób źródeł powoduje, że jest trudniejsze do naukowej eksploracji. Badania nad prawnokarną sferą aktywności Rzymian, pomimo znaczącego nadrobienia zaległości w ostatnich kilkudziesięciu latach, wciąż łączą się z naturalną potrzebą rozwiązywania przede wszystkim problemów o znaczeniu fundamentalnym. $Z$ pewnością należy do nich kwestia istoty rzymskiego crimen $^{25}$. Ciekawość wyposażonego we współczesne schematy myślowe historyka prawa prowadzi do postawienia kluczowego pytania o sposób pojmowania przez Rzymian bezprawności przestępstwa prawa publicznego. Czy zbliżał się on do metody formalnej, gdzie o bycie przestępstwa decydowało samo naruszenie ustawy karnej, czy bardziej do metody materialnej, gdzie czyn powinien być niebezpieczny dla stosunków społecznych (niebezpieczeństwo społeczne, szkodliwość społeczna czynu)? Z pozoru mogłoby się wydawać, że rzymskie spojrzenie na crimen było typowo formalne ${ }^{26}$.

${ }^{21}$ K. Amielańczyk, Obecność i znaczenie zasady słuszności w rzymskim prawie karnym, „Studia Iuridica Lublinensia" 2011, t. 15, s. 29-45.

22 W. Dajczak, Dobra wiara jako symbol europejskiej tożsamości prawa, Poznań 2006.

${ }_{23}$ Zob. przede wszystkim monografię T. Giaro, Römische Rechtswahrheiten. Ein Gedankenexperiment, Frankfurt am Main 2007.

24 B. Sitek, Pojęcie sprawiedliwości w konstytucjach cesarskich z okresu Dioklecjana i Konstantyna, Kraków 1996. Zob. też: M. Kuryłowicz, Rzymskie sentencje prawnicze o człowieku, sprawiedliwości i prawie, „Palestra” 1988, t. 32, nr 7, s. 71 i n.

25 Problematyką tą jako pierwszy w polskiej literaturze zajął się W. Mossakowski, Czyn karalny wedlug koncepcji Klaudiusza Saturnina, „Acta Universitatis Wratislaviensi. Prawo CCCV. Studia Historycznoprawne", tom poświęcony pamięci Profesora Edwarda Szymoszka, red. A. Konieczny, Wrocław 2008, s. 222 i n.

26 Zob. wiecej: K. Amielańczyk, Crimina legitima ..., s. 99 i n. 
Po pierwsze, dlatego, że ze źródeł rzymskich wyłania się procesowe podejście do crimen. Tylko taki czyn był przestępstwem, który doczekał się aktu oskarżenia wniesionego przez prywatnego oskarżyciela, ryzykującego zresztą popełnieniem kalumni. Akt oskarżenia - uzewnętrzniający rzymską accusatio, którego wymogi znamy dzięki przekazowi Paulusa - musiał zawierać oprócz okoliczności faktycznych, takich jak miejsce i czas popełnienia czynu, wskazanie ustawy karnej, którą zdaniem oskarżyciela sprawca naruszył. Nie wymagał wskazywania na stopień szkodliwości czynu, okrucieństwo sprawcy, określania rodzaju czy wysokości żądanej kary odpowiedniej do wagi przestępstwa. Nieprzypadkowo na określenie oskarżenia oprócz accusatio używano także terminu crimen (w języku łacińskim crimen to nie tylko przestępstwo, ale i oskarżenie). Ponadto na próżno szukać w prawie rzymskim takich klauzul generalnych, jak ,szkodliwość społeczna” czy „społeczne niebezpieczeństwo czynu”. Czy oznacza to, że dla pojmowania przestępstwa rzymskiego były one zupełnie obojętne? Wydaje się, że nie. Za taką hipotezą może stać konstrukcja dolus malus.

Rzymianie, co do zasady, za crimina, i to od najdawniejszych czasów, uważali czyny zamierzone, popełnione umyślnie. Zamiar popełnienia przestępstwa był określany co najmniej od czasów króla Numy Pompiliusza (VII w. p.n.e.) terminem dolus. Termin ten jest znany z najdawniejszego zachowanego przepisu przeciwko umyślnemu zabójstwu autorstwa tegoż władcy: Si qui liberum hominum dolo sciens mortui duit parricidas esto („Jeśli ktoś człowieka wolnego z premedytacją pozbawi życia, uznany będzie za ojcobójcę") ${ }^{27}$. Od pewnego momentu historii, trudno wskazać jak odległego, do terminu dolus przylgnął jednak przymiotnik malus. W każdym razie łączenie przymiotnika malus z dolus stało się już powszechną regułą w licznych leges iudiciorum publicorum, czyli w ustawach głównie Sulli i Augusta, uchwalonych u schyłku republiki rzymskiej. Nie pozostaje nic innego, jak spróbować rozstrzygnąć o jego funkcji ${ }^{28}$.

Zacząć trzeba od tego, że termin dolus, występujący tak w rzymskim prawie prywatnym, jak i karnym publicznym, miał wiele znaczeń. Do najważniejszych należały: zły zamiar, podstęp, oszustwo ${ }^{29}$, umyślność, czy szerzej: wola

27 Termin sciens dolo malo wymagał w pełni świadomego, co do faktu i co do prawa, działania sprawcy przestępstwa. Por. idem, Dolus malus - animus occidendi: The Problem of Guilt in the lex Cornelia de sicariis et veneficis, [w:] Au-delà des frontières. Mélanges de droit romain offerts à Witold Wołodkiewicz, Warszawa 2000, s. 2 i n. Z kolei G.D. MacCormack (Dolus in Republican Law, "BIDR" 1985, No. 27, s. 2) uważał, że wiedza dotyczyła szczególnego stanu sprawy ("knowledge of a particular state of affairs"). Zob. także: idem, Sciens dolo malo, [w:] Sodalitas. Scritti in onore di Antonio Guarino, Napoli 1983, s. 1448 i n.

28 Gdyby dolus posiadał dodatek malus jedynie w przekazie o lex Cornelia de sicariis et veneficis, można by przypuszczać, że być może chodziło o ekskulpacje w ten sposób licznych przypadków „zabójstwa uprawnionego”. Jednak dolus malus jest powszechny i uniwersalny w całym rzymskim ustawodawstwie karnym.

29 W. Litewski, Stownik encyklopedyczny prawa rzymskiego, Kraków 1998, s. 77. 
popełnienia czynu zabronionego, czyn złej wiary sprzeczny z prawdą, sprawiedliwością i słusznością ${ }^{30}$. Zauważyć można, że powyższe znaczenia łączy zawsze pejoratywne zabarwienie. Wydawałoby się, że niezależnie od kontekstu wypowiedzi każdy rodzący skutki prawne dolus powinien być uznany z góry za malus, bez potrzeby dodawania tego przymiotnika. Dołączenie malus do dolus powoduje wrażenie klasycznego pleonazmu, błędu językowego podobnie brzmiącego, jak przykładowo: „pełny komplet”, „akwen wodny” czy „potencjalna możliwość”, o „maśle maślanym” nie wspominając. Jak się jednak okazuje z lektury wprawdzie nielicznych źródeł dotyczących prawa okresu republiki rzymskiej, okresu, gdy działali wcześni juryści - veteres, niekiedy posługiwano się pozornym oksymoronem, tj. terminem dolus bonus. Używano go na określenie przypadków użycia „szlachetnego podstępu”, sprytu, gdy ktoś przykładowo sprytnie zachwalał zalety sprzedawanej rzeczy czy używał fortelu w słusznej sprawie, np. wyprowadzając w pole wroga lub umiejętnie zwodząc rozbójnika (latro). Dlatego juryści republikańscy Servius Sulpicius Rufus i Marcus Antistius Labeo, o czym informował kilka wieków później Ulpian, tworząc definicję podstępu rodzącego ze strony prawa przewidziane sankcje, dodawali określenie przymiotnikowe malus, mające uściślić, czy też podkreślić, że chodzi w tym przypadku o zły podstęp, o zachowanie oceniane jako naganne. W rzymskim prawie prywatnym, gdzie dolus był bardzo ważnym i często używanym terminem, traktowanym zarówno jako wada oświadczenia woli, podstawa zarzutu procesowego, najwyższy stopień winy dłużnika, jak i jeden z deliktów prawa pretorskiego, określenie malus jako dodatek do dolus się nie przyjęło. W okresie klasycznym prawa rzymskiego i później prawdopodobnie nie było już przez jurystów w ogóle używane. Wystarczał sam dolus ${ }^{31}$.

Tymczasem inną zgoła historyczną drogę przeszedł dolus w rzymskim prawie karnym publicznym ${ }^{32}$. Powrócić trzeba do poczynionej wcześniej, ale pierwszorzędnej uwagi, że dolus w rzymskich ustawach karnych oznaczał nie tylko oszustwo i podstęp, choć takie znaczenie też daje się odnaleźć, ale przede wszystkim formę winy, umyślność, zamiar sprawczy, czyli kategorię uniwersalną, odnoszącą się do wszelkich przestępstw, a nie tylko tych polegających na oszu-

30 Tak: J. Sondel, Słownik łacińsko-polski dla prawników i historyków, Kraków 1997, s. 307.

31 H. Kupiszewski (Prawo rzymskie a współczesność, wyd. 2, Kraków 2013, s. 313 i n.) twierdził, że w późnym prawie klasycznym dolus oznaczał każde naganne postępowanie, więc określenia dolus i malus straciły rację bytu. Z kolei J. Sondel (op. cit., s. 307) pod hasłem dolus bonus zamieścił uwagę, że termin ten był rozumiany, zwłaszcza przez wczesnych jurystów, jako podstęp zastosowany przeciwko wrogowi, złodziejowi.

32 Zob. L. Garofalo, Pojęcia i żywotność rzymskiego prawa karnego, ,Zeszyty Prawnicze UKSW" 2003, z. 3.1, s. 17 i n.; K. Amielańczyk, The Guilt of the Perpetrator, "Labeo" 2000 , Vol. 46, No. 1, s. 82 i n.; idem, Wina jako przesłanka odpowiedzialności karnej w prawodawstwie cesarza Hadriana, [w:] Przez tysiąclecia: państwo - prawo-jednostka, red. A. Lityński, M. Mikołajczyk, Katowice 2001, s. 20 i n. 
kańczym wprowadzeniu kogoś w błąd. Klauzula dolo jest powtarzana niemal we wszystkich zachowanych fragmentach pochodzących z ustaw Korneliusza Sulli, Pompejusza, Cezara i Augusta jako opisująca konieczną cechę działania sprawcy przestępstwa ${ }^{33}$. Jednak dolus w stosunku do ustawy królewskiej Numy doznał już $\mathrm{w}$ republice wzbogacenia o przymiotnik malus i w takim połączeniu, odmiennie niż w prawie prywatnym, przetrwał aż do czasów kodyfikacji Justyniana ${ }^{34}$. Czy pełnił zatem w prawie karnym jakąś szczególną funkcję, czy był tylko nic nieznaczącym podkreśleniem, ozdobnikiem, swoistym pleonazmem?

Wiele wskazuje na to, że określenie malus („zły”) miało mieć znaczenie wartościujące, nadające całemu zwrotowi dolus malus charakter klauzuli generalnej. Przez dołączenie słowa malus, sam termin dolus mógł powrócić do technicznego znaczenia jako „zamiaru”, w którym poznaliśmy go jeszcze w ustawie królewskiej Numy. Dolus malus to zatem „zły”, „naganny” zamiar. Niestety, z uwagi na powściągliwość jurystów rzymskich w podejmowaniu problemów prawa karnego publicznego, nie znajdziemy zbyt wiele materiału, który pokazywałby, czy i w jakim zakresie sędziowie pochylali się nad znaczeniem terminu malus oraz jaką stosowali argumentację, przypisując działanie dolo malo konkretnemu sprawcy. Więcej powiedziałyby na ten temat konstytucje cesarskie, zwłaszcza reskrypty, mające zresztą, podobnie jak responsa, charakter źródeł prawa obowiązującego.

Znowu, sięgając do kwestii dla rzymskiego prawa karnego fundamentalnych, należałoby być może pochylić się w pierwszej kolejności nad problemem potwierdzonej karalności czynów nieumyślnych na podstawie rzymskich ustaw karnych zawierających wymóg działania przez sprawcę dolo malo. Zwłaszcza że w powszechnym przekonaniu Rzymianie wymagali z reguły umyślności działania sprawcy, aby móc ukarać go karą publiczną. Już od czasów wspomnianego Numy Pompiliusza i Ustawy XII Tablic sprawcy nieumyślnemu pobłażano, ograniczając się do nałożenia w takich przypadkach obowiązku złożenia ofiary przebłagalnej z baranka.

Jedna z najważniejszych rzymskich ustaw karnych, ustawa Korneliusza Sulli przeciwko nożownikom i trucicielom, którą w uproszczeniu, choć nieściśle, nazwijmy ustawą przeciwko zabójstwu, wymagała od sprawcy działania dolo malo ${ }^{35}$. Czy można było na jej podstawie karać zabójstwa nieumyślne? Na pierwszy rzut oka - nie. Wszystkie stany faktyczne zamieszczone w ustawie zawierały bowiem wymóg umyślności, z którym nieodłącznie kojarzy się z dolus. Można nawet przypuszczać, że $w$ istocie Rzymianie ścigali na jej podstawie przede

33 Zob. więcej: K. Amielańczyk, Crimina legitima ..., s. 126 i n.

34 Podobnie w D. 48, 8, 3, 2-3 malo animo (,w złym zamiarze”), a także malo exemplo („nierozważnie") w D. 48, 8, 3, 2 (ostatnie zdanie).

35 Mowa o lex Cornelia de sicariis et veneficis. Zob. w szczególności: J.D. Cloud, The Primary Purpose of the Lex Cornelia de sicariis, "ZSS" 1969, Nr 86; idem, Leges de sicariis: The First Chapter of Sulla's lex de sicariis, "ZSS" 2099, Nr 126; K. Amielańczyk, Lex Cornelia de sicariis et veneficis. Ustawa Korneliusza Sulli przeciwko nożownikom i trucicielom, Lublin 2011. 
wszystkim zabójstwa umyślne, bo taki był, jak już dawno w nauce wykazano, policyjny cel ustawy Sulli. Dysponujemy jednak przekazem Ulpiana o pewnym reskrypcie cesarza Hadriana, rzucającym światło na szersze pojmowanie dolus malus co najmniej w II w. n.e. Sędzia miał do rozstrzygnięcia sprawę w oparciu o przepisy owej ustawy Sullańskiej. Mianowicie oskarżono pewnego młodego człowieka, Ewarysta, o spowodowanie śmierci swego kolegi podczas swawolnej zabawy polegającej na podrzucaniu go wraz z kompanami na rozciągniętym płaszczu. Choć przyczyną wypadku były „młodzieńcze nieposkromione żądze” (culpa cupiditatis), jak pisał Ulpian, działanie sprawcy było niewątpliwie nieumyślne, przypadkowe. Sędzia Ignatus Taurinus, wiedziony założeniem, że kara ma stanowić walor wychowawczy, zdecydował się jednak na wymierzenie oskarżonemu kary - choć łagodnej i nieznanej ustawie Sulli - pięcioletniej relegacji. Przed wydaniem wyroku postanowił zapytać cesarza, czy kara będzie słuszna. Cesarz w swej odpowiedzi, wydanej w formie reskryptu, przypomniał, że przestępstwa można dokonać zarówno umyślnie, tj. z zamiarem (consulto), jak i nieumyślnie, przypadkowo (casu). Działanie Ewarysta, choć nieumyślne, zostało określone jako naganne, wynikające z braku wyobraźni związanego ze swawolą (lascivia) i wymagającego kary ${ }^{36}$. Kazus jest w literaturze przedstawiany przede wszystkim jako dowód karalności co najmniej od czasów Hadriana przestępstw nieumyślnych ${ }^{37}$. Można także zasadnie wywodzić, że reskrypt stanowił przykład prawotwórczej interpretacji oryginalnej lex Cornelia przez prawo cesarskie. Jak się zdaje, mamy tu jednak do czynienia przede wszystkim z przykładem wypełnienia treścią przez cesarza oraz stosującego prawo sędziego klauzuli generalnej, jaką stanowił dolus malus, który w tym przypadku towarzyszył wprawdzie nieumyślnemu spowodowaniu śmierci, ale w sposobie działania oskarżonego dostrzeżono pewien stopień natężenia złej woli. Temin malus dodany do dolus pozwalał więc na szacowanie naganności działania sprawcy nawet wtedy, gdy sprawca dopuścił się przestępstwa nieumyślnego.

Innym przykładem relacji może być wypowiedź Ulpiana na temat Lex Iulia peculatus, wymierzonej przeciwko urzędnikom dopuszczającym się defraudacji pieniędzy publicznych ${ }^{38}$. Ustawa wymagała zapewne co do każdego z wymienio-

36 Por. V. Marotta, Multa de iure sanxit. Aspetti della politica del diritto di Antonino Pio, Milano 1988, s. 202.

37 Zob. zwłaszcza: A. Wacke, Fahrlässige Vergehen im römischen Strafrecht, "RIDA" 1979, Nr 26, s. 505 i n.; E. Höbenreich, Überlegungen zur Verfolgung unbeabsichtiger Tötungen von Sulla bis Hadrian, "ZSS" 1990, Nr 107, s. 249 i n.

38 D. 48, 13, 1 (Ulpianus libro 44 ad Sabinum): Lege Iulia peculatus cavetur, ne quis ex pecunia sacra religiosa publicave auferat neve intercipiat neve in rem suam vertat neve faciat, quo quis auferat intercipiat vel in rem suam vertat, nisi cui utique lege licebit: neve quis in aurum argentum aes publicum quid indat neve immisceat neve quo quid indatur immisceatur faciat sciens dolo malo, quo id peius fiat. 
nych w niej zachowań istnienia po stronie sprawcy dolus malus, lecz dla ostatniego ze wskazanych w przekazie stanów faktycznych znaczenie klauzuli mogło być szczególne, skoro właśnie przy nim dopiero Ulpian o dolus malus wspomniał. Chodzi tu o działanie polegające na umożliwieniu innej osobie zabrania, przejęcia albo zdefraudowania pieniędzy przeznaczonych na cele sakralne, religijne czy publiczne. Działanie takie mogło być podjęte z różnych pobudek i w różnych okolicznościach. Łatwo sobie wyobrazić sytuację faktyczną, w której ktoś nieumyślnie umożliwił innej osobie dostęp do pieniędzy publicznych, nie przewidując, że ta osoba dopuści się ich przywłaszczenia. W takim przypadku powinno się dokonać oceny ewentualnej naganności jej postępowania.

Podobnie maiestas - przestępstwo obrazy majestatu polegające na zniszczeniu posągu cesarza mogło być przede wszystkim umyślne, zamierzone, ale sprawca mógł nie mieć świadomości, że niszczy pomnik cesarza albo samo zniszczenie mogło być przypadkowe. Kwalifikacja tego czynu jako karalnego zależała od świadomości sprawcy, że dokonuje obrazy cesarza - należało więc dokonać odpowiedniej oceny naganności czynu, natężenia złej woli sprawcy, co znowu umożliwiała klauzula dolo malo ${ }^{39}$.

Na zakończenie tych krótkich, wartych na pewno pogłębienia, rozważań, nasuwają się następujące wnioski:

1. W prawie rzymskim prywatnym klauzule generalne, choć niepoddawane teoretycznej analizie jako niezależne, wyodrębnione byty prawne, swą obecność zaznaczały jednak znacznie silniej, niż to się dzieje współcześnie. Nie występowały bowiem tylko na marginesie prawa, lecz stanowiły jego istotną część wyróżniającą, może nawet fundament, realizując - jak się wydaje, lepiej niż dzisiaj - postulat elastyczności systemu prawa. Wykazując swą utrwaloną użyteczność argumentacyjną, są dowodem na słuszność rzymskiego przekonania, że nie jest najlepszym pomysłem ciągłe zwiększanie liczby przepisów w pogoni za nieosiągalnym celem, jakim byłby stan prawny, w którym każdy problem, wygenerowany kiedykolwiek przez dowolny stan faktyczny, znajdowałby natychmiast swe precyzyjne rozwiązanie w „pasującej” doń expressis verbis normie prawa stanowionego.

2. Znaczące miejsce zajmowane przez klauzule generalne $w$ argumentacji jurysprudencyjnej, ale także w edykcie pretorskim i reskryptach cesarskich, okazało się dla prawa rzymskiego niezwykle inspirujące. Ciągły dyskurs prowadzony między uczonymi prawnikami, aktywność pretora $\mathrm{w}$ ramach corrigendi vel supplendi civilis gratia oraz cesarskie reskrypty stymulowały

39 Zob. wiecej: K. Amielańczyk, Crimina legitima ..., s. 236 i n. 
rozwój prawa, jednak nie przez mnożenie przepisów, lecz przez ich ciągłą interpretację. W tym znaczeniu prawo rzymskie stawiało orzekającym sędziom wyższe wymagania intelektualne, wymagało większej samodzielności myślenia i analizowania każdego przypadku z osobna pod kątem słuszności i sprawiedliwości tkwiącej w wyroku. Można rzec, iż bardziej ufało kompetencjom i zaangażowaniu sędziów. Współcześni sędziowie od takiej „sprawiedliwościowo-słusznościowej” refleksji czują się w większości przypadków zwolnieni, gdyż ich zadaniem jest przede wszystkim znalezienie odpowiedniego przepisu prawa i proste jego zastosowanie. Zresztą od takiej refleksji zwalnia ich dzisiejszy system prawa, nastawiony na swoistą omnipotencję: regulowanie wszystkiego, co tylko wyobraźnia prawodawcy podpowie, tak jakby brakowało mu wiary, że sędziowie - z braku wystarczająco szczegółowo brzmiącego przepisu prawa - nie będą potrafili wydać sprawiedliwego orzeczenia.

3. Rzymskie klauzule generalne najczęściej pojawiały się $\mathrm{w}$ argumentacji prawniczej jurysprudencji klasycznej i odwoływały się z reguły do etycznych, często wręcz moralizatorskich ocen, co pozwoliło na nadanie samej refleksji prawniczej jurystów szlachetnego, wręcz „uświęconego" charakte$\mathrm{ru}^{40}$. Ponieważ, jak była już o tym mowa, prawo rzymskie było w powszechnym oglądzie głównie jurysprudencyjne, mogło uzyskać przez propagowanie zgodności prawa i etyki przymiot uniwersalności i ponadczasowości oraz stać się źródłem inspiracji wiecznie żywym.

4. Znaczenie klauzul generalnych $\mathrm{w}$ rzymskim prawie karnym publicznym było zdecydowanie mniejsze. Mogło to wynikać z funkcji przepisów karnych w autorytarnym państwie rzymskim, zaprzęgniętych do realizacji celów utrzymania porządku i bezpieczeństwa publicznego, gwarantujących przede wszystkim samej władzy stabilne trwanie. Miejsca na swobodny dyskurs jurysprudencji, dotyczący instytucji prawa karnego, pozostawiono niewiele. Ogólniejsza klauzula dolo malo może zatem uchodzić za jeden z niewielu wyjątków pozostawienia sędziom swobody decyzyjnej. W jakim zakresie z niej korzystali, trudno jednak, z braku źródeł, powiedzieć.

$\mathrm{Z}$ treści cytowanych ustaw karnych i przekazów źródłowych pochodzących od jurystów klasycznych wyłania się pojęcie dolus jako świadomego i moralnie nagannego zamiaru popełnienia czynu ${ }^{41}$. Dolus domagał się jednak zróżnicowanego wartościowania. W rezultacie rozwoju prawa karnego uznano, że ocena bezprawności czynu stanie się lepsza przez szacowanie stopnia tej naganności $\mathrm{w}$ procesie stosowania prawa dzięki połączeniu przymiotnika malus z dolus.

40 Jurystów nazywano „kapłanami sprawiedliwości”. Por. M. Kuryłowicz, Sacerdotes iustitiae, [w:] Ecclesia et status, Lublin 2004, s. 699 i n.

${ }_{41}$ W. Litewski, Podstawowe wartości prawa rzymskiego, Kraków 2001, s. 41, 42, a zwłaszcza 169. 
W ten sposób otworzyła się także droga do karalności przestępstw nieumyślnych. W konsekwencji przybliżało to Rzymian do postrzegania przestępstwa karnego również w sposób materialny. Wskazując na ładunek złej woli (natężenie złej woli) ${ }^{42}$, tkwiące w określeniu dolus malus, dotykali bowiem w rzeczy samej kryterium szkodliwości społecznej przestępstwa karnego.

\section{BIBLIOGRAFIA}

Amielańczyk K., Crimina legitima w rzymskim prawie publicznym, Lublin 2013.

Amielańczyk K., Dolus malus - animus occidendi: The Problem of Guilt in the lex Cornelia de sicariis et veneficis, [w:] Au-delà des frontières. Mélanges de droit romain offerts à Witold Wolodkiewicz, Warszawa 2000.

Amielańczyk K., Lex Cornelia de sicariis et veneficis. Ustawa Korneliusza Sulli przeciwko nożownikom i trucicielom, Lublin 2011.

Amielańczyk K., Obecność i znaczenie zasady stuszności w rzymskim prawie karnym, „Studia Iuridica Lublinensia" 2011, t. 15.

Amielańczyk K., The Guilt of the Perpetrator, "Labeo" 2000, Vol. 46, No. 1.

Amielańczyk K., Wina jako przesłanka odpowiedzialności karnej w prawodawstwie cesarza Hadriana, [w:] Przez tysiąclecia: państwo - prawo - jednostka, red. A. Lityński, M. Mikołajczyk, Katowice 2001.

Cloud J.D., Leges de sicariis: The First Chapter of Sulla's lex de sicariis, "ZSS” 2099, Nr 126.

Cloud J.D., The Primary Purpose of the Lex Cornelia de sicariis, “ZSS” 1969, Nr 86.

Dajczak W., Btędy poznawcze a tęsknota za użytecznościa prawa rzymskiego, „Forum Prawnicze” 2013, z. 3.

Dajczak W., Dobra wiara jako symbol europejskiej tożsamości prawa, Poznań 2006.

Dajczak W., „Natura umowy” w argumentacji prawników rzymskich, [w:] Consul est iuris et patriae defensor. Ksiegga pamiatkowa dedykowana Andrzejowi Kremerowi, Warszawa 2012.

Dajczak W., The Nature of the Contract in Reasoning of Civilian Jurists, Poznan 2012.

Dajczak W., Giaro T., Longchamps de Bérier F., Prawo rzymskie. U podstaw prawa prywatnego, wyd. 2, Warszawa 2014.

Garofalo L., Pojęcia i żywotność rzymskiego prawa karnego, „Zeszyty Prawnicze UKSW” 2003, z. 3.1 .

Giaro T., Interpretacja jako źródto prawa - dawniej i dziś, „Studia Prawnoustrojowe” 2007, nr 7.

Giaro T., Römische Rechtswahrheiten. Ein Gedankenexperiment, Frankfurt am Main 2007.

Horak F., Rationes decidendi. Entscheidungsbegründungen bei den alteren römischen Juristen bis Labeo, Insbruck 1969.

Höbenreich E., Überlegungen zur Verfolgung unbeabsichtiger Tötungen von Sulla bis Hadrian, “ZSS" 1990, Nr 107.

Kupiszewski H., Prawo rzymskie a wspótczesność, wyd. 2, Kraków 2013.

Kuryłowicz M., Prawo rzymskie. Historia - tradycja - współczesność, Lublin 2003.

Kuryłowicz M., Rzymskie sentencje prawnicze o człowieku, sprawiedliwości i prawie, „Palestra” 1988, t. 32, nr 7 .

Kuryłowicz M., Sacerdotes iustitiae, [w:] Ecclesia et status, Lublin 2004.

Kuryłowicz M., Wokót pojęcia aequitas w prawie rzymskim, „Studia Iuridica Lublinensia” 2011, t. 15. Leszczyński L., Pojęcie klauzuli generalnej, „Annales UMCS. Sectio G” 1991, nr 38.

${ }^{42}$ Takie zwroty, jak „nasilenie złej woli” bądź „natężenie złej woli” to kategorie często używane współcześnie w uzasadnieniach orzeczeń polskich sądów karnych. 
Leszczyński L., Tworzenie generalnych klauzul odsyłających, Lublin 2000.

Litewski W., Jurysprudencja rzymska, Kraków 2000.

Litewski W., Podstawowe wartości prawa rzymskiego, Kraków 2001.

Litewski W., Słownik encyklopedyczny prawa rzymskiego, Kraków 1998.

MacCormack G.D., Dolus in Republican Law, "BIDR" 1985, No. 27.

MacCormack G.D., Sciens dolo malo, [w:] Sodalitas. Scritti in onore di Antonio Guarino, Napoli 1983.

Marotta V., Multa de iure sanxit. Aspetti della politica del diritto di Antonino Pio, Milano 1988.

Mossakowski W., Czyn karalny wedlug koncepcji Klaudiusza Saturnina, „Acta Universitatis Wratislaviensi. Prawo CCCV. Studia Historycznoprawne", tom poświęcony pamięci Profesora Edwarda Szymoszka, red. A. Konieczny, Wrocław 2008.

Nowacki J., O przepisach zawierających klauzule generalne, [w:] Studia z teorii prawa, Kraków 2003.

Nowicka D., Zniestawienie w prawie rzymskim, Wrocław 2013.

Radwański Z., Zieliński M., Uwagi de lege ferenda o klauzulach generalnych w prawie prywatnym, „Przegląd Legislacyjny” 2001, nr 2.

Rozwadowski W., Etiam clarum iu exigit interpretationem, [w:] W poszukiwaniu dobra wspólnego. Księga jubileuszowa Profesora Macieja Zielińskiego, red. A. Choduń, S. Czepita, Szczecin 2010.

Sitek B., Pojęcie sprawiedliwości w konstytucjach cesarskich z okresu Dioklecjana i Konstantyna, Kraków 1996.

Sondel J., Stownik łacińsko-polski dla prawników i historyków, Kraków 1997.

Wacke A., Fahrlässige Vergehen im römischen Strafrecht, "RIDA" 1979, Nr 26.

Wolter A., Ignatowicz J., Stefaniuk K., Prawo cywilne. Zarys części ogólnej, Warszawa 2001.

\section{SUMMARY}

The Roman iuris prudentes used with predilection the evaluative sentences, reminding contemporary general clauses, making the Roman law itself flexible and timeless. In the private law the sentences like bona fides (good faith), bonum et equum (good and right), ratio aequitatis (right reasons), utilitas (utility), natura rerum (nature of things) presented such character. In the penal law the role of the general clauses has been limited, but the expressions like utillitas publica (public interest) or dolus malus (wrong intention) have been presented as well.

Keywords: values of Roman law; general clauses; good faith; wrong intention

\section{STRESZCZENIE}

Rzymscy iuris prudentes z upodobaniem używali zwrotów wartościujących, przypominających współczesne klauzule generalne, nadając prawu rzymskiemu elastyczność i ponadczasowość. W prawie prywatnym charakter takich zwrotów miały przykładowo: bona fides (dobra wiara), bonos mores (dobre obyczaje), bonum et equum (dobre i słuszne), ratio aequitatis (słuszne powody), utilitas (użyteczność), natura rerum (natura rzeczy). W prawie karnym rola klauzul generalnych była mniejsza, ale także można odnaleźć stosowne ich przykłady, jak choćby: utillitas publica (korzyść, interes publiczny) czy dolus malus (zły zamiar).

Słowa kluczowe: wartości prawa rzymskiego; klauzule generalne; dobra wiara; zły zamiar 